\title{
IgG4-Related orbital disease in patients with diabetic retinopathy: Effects of glucan and vitamin D supplementation
}

\begin{abstract}
Richter Josef ${ }^{1}$, Závorková Martina² ${ }^{2}$ Vetvicka Vaclav ${ }^{1 *}$, Král Vlastimil', Stiborova Ivana ${ }^{1}$, Liehneová Ivana ${ }^{1}$ and Pohořská Jitka ${ }^{1}$ and Rajnohova Dobiasova Lucie ${ }^{1}$
\end{abstract}

${ }^{*}$ Correspondence: Vaclav.vetvicka@louisville.edu

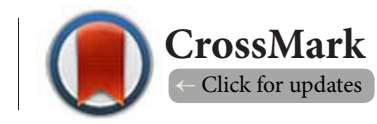

'Zdravotní ústav se sídlem v Ústínad Labem, Usti nad Labem, Czech Republic, Europe.

${ }^{2}$ Oční klinika UJEP Masarykovanemocnice, Krajskázdravotní, a.s., Usti nad Labem, Czech Republic, Europe.

\begin{abstract}
Background: Diabetic retinopathy represents a serious complication of diabetes.

Methods: In our group of 52 patients, we identified 7 individuals (13\%) with elevated levels of IgG4.

Results: Detailed examination revealed significant clinical changes, resulting in a diagnosis of probable IgG4-RD.

Conclusions: Long-term evaluation and beta glucan supplementation, combined with vitamin D supplementation, during general treatment of these patients significantly improved both health and mental conditions.
\end{abstract}

Keywords: IgG, IgG4-RD, glucan, vitamin D

\section{Introduction}

Diabetic retinopathy (DR) is a highly specified neurovascular complication of type1 (DM1) or type 2 diabetes mellitus (DM2). $\mathrm{DR}$ is the most common cause of vision loss in people between the ages of 20 and 75 years. DR is the fifth most common preventable cause of serious vision damage and blindness. The most common risk factors involved in DR progression include the duration of diabetes, hyperglycemia, hypertension, obesity, smoking, high levels of lipids, and high insulin levels $[\mathbf{1 , 2}]$. The prevalence of DR in different countries can reach up to $50 \%$ [1-3]. The latest studies,over a 10-year period, demonstrate that intensive monitoring and control of glycemia levels strongly lowers the risk of DR progression [1,2]. Some studies recommended evaluation of the possible effects of dyslipidemia on DR progression. In up to $10 \%$ of diabetic patients, DR was observedfrom the first manifestation of diabetes, which strongly suggests the importance of early diagnosis of DM2.

Monitoring nutritional parameters and their effects can be an important contribution towards the reduction of DM2 induction. Products of oxidative stress activate alternative complement pathways, triggering lower level inflammatory reactions (pathophysiologic parainflammation) and leading to increased production of C-reactive protein. This protein, together with additional proteins, triggers chronic inflammation. It is clear that mutual relations of mechanisms mentioned above affect vascular, neural, glial, and immune systems, which are damaged by diabetes mellitus [4]. Lately, much attention is focused on theassociation between vitamin $D$ deficit and risk of diabetes and subsequent DR [5-10]. Both experimental work and population studies confirmed significant positive effects of glucan supplementation in diabetics. Carbohydrates represent a key component in regulating glucose levels. Glucan can be effective either alone or as part of natural food sources $[11,12]$.

This study was based on the hypothesis that interaction between risk factors of DR can be increased by immunological stress, particularly nonspecific immunity. We perform a detailed immunological observation of 52 patients diagnosed with DRand diabetic macular edema $[4,13,14]$. This complex investigation foundseven individuals with high levels of IgG4 subclass.

Hamano and colleaguesnot only described elevated levels of IgG4 in autoimmune pancreatitis, but also prepared the basis for diagnostic and inspired health professionals from various 
Richter et al., Pathology Discovery 2018,

disciplines to follow complications of diseases connected with IgG4 levels, which are now defined as IgG4-RD [15]. A high level of IgG4 alone does not indicate a diagnosis of IgG4-RD and should be evaluated together with additional laboratory and clinical results [16-22]. IgG4-ROD (IgG4-related ophthalmic disease) is a recently recognizedfibroinflammatory disorder characterized by lymphoplasmacytic infiltrates with large numbers of IgG4-positive plasma cells, eosinophil infiltration, and storiform fibrosis $[\mathbf{7 , 1 4 , 2 3 ]}$. In addition, IgG4-ROD is the latest condition to account for some lesions previously labeled as idiopathic orbital inflammation [24]. Both orbital and extraorbital manifestations are often connected with impairments of other organs [17]. To our knowledge, lgG4ROD has not been described in patients with $D R$, which led us to do an extensive evaluation of laboratory and clinical parameters of our seven patients $[1,3,14,17,20]$.

\section{Material and methods Patients}

From a group of 52 patients diagnosed with diabetic retinopathy and diabetic macular edema, we evaluated7 patients (6 males and 1 female) with elevated levels of IgG4. Detailed characteristics of these patients are summarized in Table 1.

\section{Protocol}

We explained the experimental protocol and obtained signed consent forms from all participating patients. This study was Institutional Review Board (Regional Masaryk University) approved and performed in full agreement with the Helsinki declaration (revised version 2000.09.01), and in full compliance with the Czech Republic's clinical testing rules.

\section{Glucan}

Yeast-derived insoluble Glucan \#300 (>85\% dry w/w basis) was purchased from Transfer Point (Columbia, SC, USA). This glucan contains $96 \%$ carbohydrates and $2.1 \%$ proteins. Neutral sugar analysis confirmed $91.3 \%$ glucose and $8 \%$ mannose. Glucan, $500 \mathrm{mg}$, was taken on an empty stomach, followed by $100 \mathrm{ml}$ of water and a 30-minute rest prior to any food intake.

\section{Vitamin D}

Vitamin D (cholecalciferol, D3) was manufactured by Merck (Darmstadt, Germany). One ml of solution contains 20,000 IU of vitamin D3, one drop contains $500 \mathrm{IU}$. All patients were instructed to ingest vitamin $D$ with fat-containing food.

\section{Tests}

Blood was taken at regular intervals over a period of 3-months from all patients. All immunological and biochemical observations necessary to follow the development of disease, together with basic treatment using subthresholdmicropulse laser of retina by an ophthalmologist, was performed.

Vitamin $D$ levels were measured by an ELISA assay using standards recommended by the manufacturer (DRG Instru- ments, Germany). Based on the manufacturer's information, average values for a healthy common 58-year-old Caucasian population are $26.1 \mathrm{ng} / \mathrm{ml}$ in males and $30.2 \mathrm{ng} / \mathrm{ml}$ in females. A vitamin $D$ deficit is considered when levels are below 10 $\mathrm{ng} / \mathrm{ml}$, insufficient levels range between $10-29 \mathrm{ng} / \mathrm{ml}$, and normal levels range between $30-100 \mathrm{ng} / \mathrm{ml}$. Samples were taken in the morning on an empty stomach.

Serum proteins were evaluated using nephelometer Siemens BM II (Siemens Health Care, Diagnostics, Germany) as suggested by the manufacturer. Relevant reagents and controls were provided by Siemens (Siemens Health Care Diagnostic Products). We measured the levels of $\lg \mathrm{A}, \lg \mathrm{G}$, and $\lg M$ and subclasses $\lg G 1, \lg G 2, \lg G 3$, and $\lg G 4$ using nephelometer Siemens BM II as suggested by the manufacturer. Relevant antibodies and controls were provided by Siemens. Evaluation employed IMMULITE 20 analyzer. IgG subclasses were determined using specific antibodies (Binding Site Group, Birmingham, Great Britain). lgG4/lgG, lgG2/lgG, and lgG2/ IgG4 ratio, resp., were determined as described $[\mathbf{1 4 , 2 5 ]}$.

Plasma levels of IL-6 were measured by IMMULITE system (Siemens) as suggested by the manufacturer. Relevant reagents and controls were provided by Siemens. Sensitivity of the test was $2 \mathrm{pg} / \mathrm{ml}$.

Evaluations of the levels of T lymphocytes and plasmablasts were based on both available literature and our own work $[\mathbf{7 , 2 0}$. Plasmablasts are given as the percentage of $\mathrm{IgM}^{-} / \mathrm{CD} 19^{+}$vs. CD19+. For evaluation, we used four-color cytometer FACS CALIBUR (BD Biosciences, USA) using antiCD19-APC, anti-CD38-PE (BD Biosciences), and anti-IgM-FITC (Dako) antibodies. For Treg evaluation, we used a combination anti-CD127-PE (Beckman Coulter, USA), anti-CD4-PerCP and anti-CD25-APC (BD Biosciences). Tregs levels are shown as percentage of $\mathrm{CD} 25^{+} / \mathrm{CD} 127^{-} / \mathrm{CD} 4^{+}$.

\section{Statistical analysis}

Paired $t$ test statistical significance was evaluated (GraphPad Prism 5.04; GraphPad Software, USA). An average and standard deviation was evaluated after determining standard value composition (D'Agostino, Pearson). In case of nonstandard composition, values were converted into logarithms.

\section{Results}

Table 1 summarizes clinical and laboratory findings in our patients. The tested group consisted of seven patients (six males, one female) diagnosed with DR, all were found in our group of 52 patients and differed only in elevated levels of IgG4. All cases demonstrated extremely low levels of vitamin D (Table 1). Therefore, we started with supplementation with vitamin D (Vigantol) in doses based on sex, phototype, age, and weight. During the winter period, these doses were increased $50 \%$. In all tested cases, we supplemented the food with vitamin $D$ and yeast-derived glucan \#300 at dose based on the patient weight, ranging from 500 to 140500 mg/day. In addition, all patients were overweight; one patient with 
Richter et al., Pathology Discovery 2018,

http://www.hoajonline.com/journals/pdf/2052-7896-6-1.pdf

Table 1. Basic characteristic of the IgG4-RD Subjects with diabetic retinopathy.

\begin{tabular}{|c|c|c|c|c|c|c|c|c|}
\hline Patients & & HD & $\mathrm{HM}$ & FV & ŽP & KM & MM & HJ \\
\hline Age & & 61 & 61 & 68 & 66 & 62 & 65 & 62 \\
\hline Gender & & $\mathrm{F}$ & $M$ & $M$ & $M$ & $M$ & $M$ & $M$ \\
\hline BMI & $\mathrm{kg} / \mathrm{m}^{2}$ & 31.59 & 36.5 & 30.47 & & 28.09 & 26.06 & 35.46 \\
\hline ABSI & $\mathrm{m}^{11 / 6} \mathrm{~kg}^{-2 / 3}$ & 0.095 & 0.086 & 0.077 & 0.079 & 0.082 & 0.086 & 0.085 \\
\hline Smoker & & & + & & & + & & \\
\hline \multicolumn{9}{|l|}{ Former smoker } \\
\hline Hypertension & & & + & + & + & + & & + \\
\hline Vitamin D & $\mathrm{ng} / \mathrm{ml}$ & 12.4 & 9.8 & 7.8 & 18.2 & 10.5 & 5 & 12.8 \\
\hline $\mathrm{Hb} 1 \mathrm{AC}$ & $\mathrm{mol} / \mathrm{ml}$ & 87 & 60 & 57 & 50 & 61 & 75 & 64 \\
\hline Total cholesterol & $\mathrm{mmol} / \mathrm{L}$ & 4.46 & 6.61 & 5.19 & 5 & 7.59 & 4.7 & 4.29 \\
\hline Triglyceride & $\mathrm{mmol} / \mathrm{L}$ & 1.31 & 4.3 & 0.71 & 1.98 & 4.96 & 3.46 & 0.82 \\
\hline $\mathrm{HDL}$ & $\mathrm{mnol} / \mathrm{L}$ & 1.16 & 0.89 & 2.64 & 1.63 & 0.96 & 1.36 & 1.33 \\
\hline LDL & $\mathrm{mnol} / \mathrm{L}$ & 2.94 & 4.46 & 2.28 & 3.08 & 5.39 & 3.05 & 2.83 \\
\hline Aterogenic index & $<4$ & 3.84 & 7.43 & 1.97 & 3.07 & 3.45 & 3.45 & 3.23 \\
\hline apolipoprotein A1 & $\mathrm{g} / \mathrm{L}$ & 1.5 & 1.38 & 1.41 & 1.89 & 1.37 & 1.56 & 1.39 \\
\hline apolipopretein B & $g / L$ & 0.89 & 1.41 & 0.76 & 1 & 1.67 & 1 & 0.88 \\
\hline Kutners syndrom & & + & & & + & & & \\
\hline Lymphadenitis & & + & + & + & & + & + & + \\
\hline Alergic disease & & & & & & & + & + \\
\hline Microvascular disease & & & & + & & & & \\
\hline Cough & & & + & + & & & & \\
\hline Fever & & + & + & + & + & + & + & + \\
\hline Arthralgia & & + & + & & + & + & & + \\
\hline Sialadenitis & & & & + & & & & \\
\hline \multicolumn{9}{|l|}{$\begin{array}{l}\text { Autoimmune } \\
\text { pancreatitis }\end{array}$} \\
\hline Autoimmune disease & & + & & & & & & \\
\hline Malignancy & & + & & & & & & \\
\hline \multicolumn{9}{|l|}{ Mild NPDR } \\
\hline Moderate NPDR & & & & + & & & & \\
\hline Severe PDR & & + & & & & & & \\
\hline \multicolumn{9}{|l|}{ No DME } \\
\hline \multicolumn{9}{|l|}{ NON-CIDME } \\
\hline CIDME & & & + & & + & + & + & \\
\hline Diabetes I & & & & & + & & & \\
\hline Diabetes II & & 12 & 24 & 3 & 18 & 22 & 21 & 17 \\
\hline Polyneuropathy & & + & + & & + & + & & + \\
\hline Diabetic nefropathy & & & & + & + & + & & \\
\hline
\end{tabular}

significantly lower BMI had a high ABSI(A Body Shape Index). Initial levels of lipid metabolism resulted from weight and dietary habits. All patients demonstrated multiple clinical impairments.Surprisingly, low rate of smoking compared to normal population was most probably reflecting socioeconomic situation of our patients.

Table 2 shows results of the laboratory examination, which focused on the definition of IgG4-RD disease. In all cases, we found higher levels of $\lg G 4$ and $\lg G 4 / \operatorname{lgG}$, and some of the $\lg G$ subclasses ( $\lg G 1, \lg G 2, \lg G 3$, and $\lg G 4)$ divided by $\lg G$. Similarly, lgG4/lgG1+lgG2 and IgG2/lgG ratios were also elevated. Inflammatory reaction with persisting elevated levels of C-reactive protein and serum amyloid $A$ is accompanied with elevated levels of orosomucoid, which reflects long-term mild inflammatory reaction [26]. We also found elevated levels of IgEin three individuals, but increased levels of specific IgG antibodies against inhaled antigens (grass, pollen, and mites) were found only in one patient. Increased levels of plasmablasts were found in four individuals.

Local treatment of DR is laser photocoagulation (thermal burn in retinal tissue by laser-generated light), used either focally or, in more advanced conditions, panretinally. In proliferative retinopathy and in treatment of its complications, such as bleeding into vitreous bodyand traction retinal 
Richter et al., Pathology Discovery 2018,

http://www.hoajonline.com/journals/pdf/2052-7896-6-1.pdf

doi: $10.7243 / 2052-7896-6-1$

Table 2. Laboratory investigation of casis with diabetic retinopathy and IgG4 - RD.

\begin{tabular}{|c|c|c|c|c|c|c|c|c|c|}
\hline \multirow[b]{2}{*}{ Parameters } & \multirow[b]{2}{*}{ reference intervals } & \multicolumn{2}{|c|}{ KM } & \multicolumn{2}{|c|}{ HD } & \multicolumn{2}{|c|}{ HM } & \multicolumn{2}{|c|}{ FV } \\
\hline & & $\begin{array}{l}\text { sample } \\
1\end{array}$ & $\begin{array}{l}\text { sample } \\
2\end{array}$ & $\begin{array}{l}\text { sample } \\
1\end{array}$ & $\begin{array}{l}\text { sample } \\
2\end{array}$ & $\begin{array}{l}\text { sample } \\
1\end{array}$ & $\begin{array}{l}\text { sample } \\
2\end{array}$ & $\begin{array}{l}\text { sample } \\
1\end{array}$ & $\begin{array}{l}\text { sample } \\
2\end{array}$ \\
\hline IgG & $7-16 \mathrm{~g} / \mathrm{l}$ & 13.3 & 15.9 & 16.1 & 19.6 & 22.4 & 21.8 & 12.8 & 22.7 \\
\hline IgG1 & $4,1-10,1 \mathrm{~g} / 1$ & 7.89 & 8.12 & 10.2 & 11.7 & 13 & 11.1 & 8.04 & 17 \\
\hline IgG2 & $1,7-7,9 \mathrm{~g} / \mathrm{l}$ & 4.48 & 4.79 & 4.52 & 4.31 & 8.56 & 6.64 & 4.46 & 5.54 \\
\hline IgG3 & $0,11-0,85 \mathrm{~g} / \mathrm{l}$ & 0.52 & 0.52 & 0.79 & 0.72 & 0.88 & 0.72 & 0.66 & 1.04 \\
\hline IgG4 & $0,03-1,8 \mathrm{~g} / \mathrm{l}$ & 1.16 & 2.07 & 2.98 & 3.29 & 2.48 & 2.93 & 1.1 & 3.25 \\
\hline IgG1 - IgG4 & 14,0 & 14.05 & 15.5 & 18.49 & 20.02 & 24.92 & 21.39 & 14.26 & 26.83 \\
\hline $\operatorname{lgG} 4 / \operatorname{lgG}(\mathrm{l})$ * & $10 \%$ & 9 & 13 & 19 & 17 & 11 & 13 & 9 & 14 \\
\hline IgG4/lgG (II) ** & $10 \%$ & 9.46 & 13.35 & 11.5 & 13.5 & 11.2 & 9.8 & 11.4 & 11.8 \\
\hline IgG2/lgG4 & $>1$ & 3.86 & 2.31 & 1.52 & 1.31 & 3.45 & 2.27 & 4.05 & 1.70 \\
\hline IgG2/lgG & $>0,3$ & 0.34 & 0.30 & 0.28 & 0.22 & 0.38 & 0.30 & 0.35 & 0.24 \\
\hline $\lg A$ & $0,7-4 \mathrm{~g} / \mathrm{l}$ & 3.86 & 3.76 & 3.84 & 4.66 & 5.13 & 4.9 & 6.87 & 7.37 \\
\hline Ig $M$ & $0,3-2,4 \mathrm{~g} / \mathrm{l}$ & 0.61 & 0.55 & 0.88 & 0.97 & 0.54 & 0.59 & 0.36 & 0.35 \\
\hline C3 & $0,75-1,4 \mathrm{~g} / \mathrm{l}$ & 1.27 & 1.33 & 1.48 & 1.47 & 1.49 & 1.49 & 1.28 & 1.41 \\
\hline C4 & $0,1-0,34 \mathrm{~g} / \mathrm{l}$ & 0.46 & 0.41 & 0.31 & 0.25 & 0.34 & 0.34 & 0.19 & 0.17 \\
\hline CRP & $0-5 \mathrm{mg} / \mathrm{l}$ & 6.3 & 6.43 & 51.1 & 3.3 & 6.36 & 12.6 & 9.08 & 29.9 \\
\hline SAA & $0-6,4 \mathrm{mg} / \mathrm{l}$ & & 30.7 & 7 & 10 & 9.16 & 11.6 & 38.5 & 3.91 \\
\hline IL-6 & $0-20 \mathrm{pg} / \mathrm{ml}$ & 2 & 5.1 & & 2.6 & 3.2 & 6.1 & 3.1 & 20.5 \\
\hline $\operatorname{Ig} E$ & $0-150 \mathrm{kU} / \mathrm{l}$ & 32 & & 199 & & 52.5 & & 191 & \\
\hline Spec. IgE & & negat & & negat & & negat & & negat & \\
\hline Orosomucoid & $0,5-1,2 \mathrm{~g} / \mathrm{l}$ & 1.19 & 1.2 & 1.25 & 0.94 & 1.4 & 1.24 & 1.38 & 1.76 \\
\hline CD 38++lgM-v CD 19+ & $0,5 \% \pm 0,5$ & & 1 & 1.2 & & 1 & & & 0.7 \\
\hline
\end{tabular}

\begin{tabular}{|c|c|c|c|c|c|c|c|}
\hline \multirow[b]{2}{*}{ Parameters } & \multirow[b]{2}{*}{ reference intervals } & \multicolumn{2}{|c|}{ ŽP } & \multicolumn{2}{|c|}{ MM } & \multicolumn{2}{|c|}{$\mathrm{HJ}$} \\
\hline & & $\begin{array}{l}\text { sample } \\
1\end{array}$ & $\begin{array}{l}\text { sample } \\
2\end{array}$ & $\begin{array}{l}\text { sample } \\
1\end{array}$ & $\begin{array}{l}\text { sample } \\
2\end{array}$ & $\begin{array}{l}\text { sample } \\
1\end{array}$ & $\begin{array}{l}\text { sample } \\
2\end{array}$ \\
\hline $\lg G$ & $7-16 \mathrm{~g} / \mathrm{l}$ & 10.8 & 12.9 & 16.4 & 14.3 & 12.8 & 12.5 \\
\hline $\lg G 1$ & $4,1-10,1 \mathrm{~g} / \mathrm{l}$ & 5.26 & 6.27 & 7.32 & 6.71 & 7.65 & 7.18 \\
\hline $\lg G 2$ & $1,7-7,9 \mathrm{~g} / \mathrm{l}$ & 5.28 & 5.44 & 6.51 & 6.34 & 4.44 & 4.1 \\
\hline $\lg G 3$ & $0,11-0,85 \mathrm{~g} / \mathrm{l}$ & 0.33 & 0.33 & 0.68 & 0.56 & 0.72 & 0.67 \\
\hline $\lg \mathrm{g} 4$ & $0,03-1,8 \mathrm{~g} / \mathrm{l}$ & 0.91 & 2.04 & 2.53 & 2.52 & 1.97 & 2.32 \\
\hline $\operatorname{lgG} 1$ - IgG4 & 14,0 & 11.78 & 14.08 & 17.04 & 16.13 & 14.78 & 14.27 \\
\hline $\lg G 4 / \lg G(I)^{*}$ & $10 \%$ & 8 & 16 & 15 & 18 & 15 & 19 \\
\hline $\operatorname{lgG} 4 / \operatorname{lgG}(\mathrm{II})^{* \star}$ & $10 \%$ & 10.9 & 10.9 & 10.4 & 11.3 & 14.79 & 16.3 \\
\hline $\lg G 2 / \lg G 4$ & $>1$ & 5.80 & 2.67 & 2.57 & 2.52 & 2.25 & 1.77 \\
\hline $\lg G 2 / \lg G$ & $>0,3$ & 0.49 & 0.42 & 0.40 & 0.44 & 0.35 & 0.33 \\
\hline $\lg A$ & $0,7-4 \mathrm{~g} / \mathrm{l}$ & 1.79 & 1.83 & 4.22 & 3.83 & 1.43 & 1.45 \\
\hline $\lg M$ & $0,3-2,4 \mathrm{~g} / \mathrm{l}$ & 0.95 & 1.16 & 1.39 & 1.36 & 0.95 & 0.91 \\
\hline $\mathrm{C} 3$ & $0,75-1,4 \mathrm{~g} / \mathrm{l}$ & 1.25 & 1.2 & 1.12 & 1.1 & 1.25 & 1.31 \\
\hline $\mathrm{C} 4$ & $0,1-0,34 \mathrm{~g} / \mathrm{l}$ & 0.33 & 0.28 & 0.27 & 0.27 & 0.36 & 0.33 \\
\hline CRP & $0-5 \mathrm{mg} / \mathrm{l}$ & 3.74 & 3.3 & 3.3 & 3.17 & 3.17 & 3.17 \\
\hline SAA & $0-6,4 \mathrm{mg} / \mathrm{l}$ & 1.69 & 1.79 & 5.1 & & 6.75 & 3.95 \\
\hline IL-6 & $0-20 \mathrm{pg} / \mathrm{ml}$ & 2 & 2.2 & 2 & & 2 & 2.6 \\
\hline $\lg E$ & $0-150 \mathrm{kU} / \mathrm{l}$ & 61.7 & & 94.6 & & 1240 & \\
\hline Spec. IgE & & negat & & negat & & 6.12 & \\
\hline Orosomucoid & $0,5-1,2 \mathrm{~g} / \mathrm{l}$ & 0.87 & 0.85 & 0.84 & 0.88 & 0.8 & 0.88 \\
\hline CD 38++lgM-v CD 19+ & $0,5 \% \pm 0,5$ & 0.2 & & 1 & & 0.4 & \\
\hline
\end{tabular}

detachment, pars plana vitrectomy (vitreous humor gel that fills the eye cavity is removed to provide better access to the retina) is used. Treatment of edema occurring in DR is based

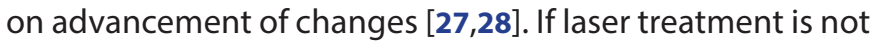
adequate, intravitreal application of vascular endothelial growth factor blockers or corticosteroids remain an option.
Another possibility is surgery performed pars plana vitrectomy with peeling of membrane limitans interna and epiretinal membrane.

\section{Discussion}

Diabetes mellitus is a chronic disease characterized by high 
Richter et al., Pathology Discovery 2018,

levels of blood glucose (hyperglycemia) with typical symptoms of feeling thirsty, polyuria, polydipsia, and weight loss [29]. Medicine recognize three types of diabetes: type I caused by T cell-mediated autoimmune destruction of B lymphocytes; type II caused by cell resistance to insulin; and type III found during pregnancy manifested by both decrease of insulin leveland increased resistance to insulin effects [25]. Prevalence of DM2 is steadily increasing, particularly in recent years. This trend is often associated with aging of the population, unhealthy nutritional habits, obesity, low physical activity, and other factors. Lately, we observed significant improvements in treatment of DM2, but obstacles remain such as restricted quality of life and increasing costs of treatment $[6,13]$.

DR is one of the most common complications of diabetes mellitus and currently affects over 100 million people worldwide [1]. This neurovascular complication can occur in patients suffering from either DM1 or DM2, and its prevalence clearly correlates with the length of disease and with the quality of glycemic control [2].

IgG4-RD represents an inflammatory process characterized by tissue infiltration of IgG4-producing lymphocytes. It is a systemic disease affecting various organs previously believed to be unrelated. For detailed information of IgG4related diseases, see review by Andrew, Kearney and Selva [24]. Since the first description of IgG4-RD with common occurrence of affected pancreas, there is an ever-increasing amount of information connecting this disease with additional tissue complications $[7,19,30]$. Lately, the attention is focused primarily on the correlation between IgG4-RD and orbital and periorbital impairment $[7,14]$. However, we found no studies describing IgG4-ROD in patients with DR in the literature. In our group of 52 patients, we found 7 patients fulfilling the criteria for IgG4-ROD diagnosis. Among these patients, there was a noticeable predominance of males, which is in agreement with the previous data [19,30,31]. Additional characteristics, such as obesity, advanced age, and high BMI and $A B S I$, suggesting high risk of sarcopenic obesity, were also consistent with current literature $[1,17,19,30,32]$. The fact that only two out of seven patients were smoking was interesting. Based on age and socioeconomic conditions, the percentage of smokers was significantly lower than in either diabetic or healthy population in the same region, where the percentage of smoking population exceeded $60 \%$. Hypertension represents significant risk in diabetics, and we found this condition in all our patients. Our findings of significant vitamin $D$ deficiency at the beginning of our study are in agreement with older studies [5,6,8-10]. In all patients with lgG4-ROD, we found this deficiency to be even stronger that in the rest of diabetic patients. In addition, findings of glycosylated hemoglobin $\mathrm{A} 1 \mathrm{C}$ were significantly higher. For some patients, lipid metabolism levels at the beginning of the study (summarized in Table 1) were in all probability distorted by long-term treatment with statins.

Elevated IgG4 levels might be connected with several additional clinical manifestations including cancer, autoimmune diseases, vasculitis (inflammation of the blood vessels) related to ANCA, and infectious diseases [7]. As we often find elevated IgG in allergic patients, it is necessary to monitor a wide range of possible clinical manifestations, which can be connected with high lgG4 levels [19]. We based our evaluation on the frequency of their occurrence, which was established by Wolfson and Hamilos [31]. During our study, we found no additional clinical impairments which would request the need of targeted therapy. In agreement with current literature, we believe it is beneficial to continue patient monitoringat regular 8-month intervals [30]. Lymphadenopathycan be asymptomatic and persist without any clinical displays. The same is true of signalization of inflammatory reaction by activation of inflammatory proteins, which can be related only to obesity of tested individuals $[13,26]$. We consider clinical manifestation of IgG4-RD to be the deciding marker $[14,15,19,31]$.

An important criterion necessary for optimal assessment of IgG4-RD diagnosis is evaluation of IgG4 levels. This level determines specificity of diagnosis to $77 \%$ and sensitivity of diagnosis to $86 \%$. IgG4 levels higher than $2.01 \mathrm{mg} / \mathrm{ml} \mathrm{sug-}$ gest specificity to be $89 \%$ and lower (80\%) sensitivity [33]. Criteria for IgG4-RD are changing and different authors use

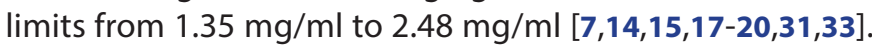
Many authors now agree that the $\mathrm{lgG} 4 / \mathrm{lg}$ g ratio is a better marker and levels above $10 \%$ are usually considered to be significant $[14,16-18,22]$. We believe that it would be better to use individual IgG subclasses rather than IgG only. Our findings suggest that the specificity of this evaluation is significantly higher. Lately, some groups have suggested using lgG2 levels and a ratio lgG2/lgG with limit $9.3 \%$ and above; or a radio lgG3/lgG4 with an over $1.0 \mathrm{mg} / \mathrm{ml} \mathrm{limit} \mathrm{[16].}$ It is important to note, however, that the importance of this index might be affected by allotype or isotype of Caucasian and Oriental races [34].

A better criterion for signalization of chronic inflammatory reaction could be evaluation of orosomucoid level. This acute phase plasma alpha globulin is a better marker of persistent inflammation than C-reactive protein, IL-6, or serum amyloid A $[3,13]$. Recent studies described galectin-3 expression in patients with IgG4-RD as an important marker of the disease activity [35]. An important benefit for precise diagnosis of IgG4-RD is evaluation of circulating plasmablasts, which is relevant during active and relapse stages of the disease $[21,36]$. Depressed complement levels could also be used for diagnosis, but we did not find this change in our patients [31].

The basis of DR treatment is to adhere to the suggested curative regiment $[1,2]$. Usually, the medical team consist of a diabetologist, an ophthalmologist, and a general practitioner. Timely involvement of these specialists is necessary for successful controlof diabetes mellitus and for prevention or reduction of its common complications. It wasPubliliusSyrus whoprofessed in the first century B.C.E. that it is better to use the medicine at the beginning of the disease than at the last moment [29]. 
Richter et al., Pathology Discovery 2018,

Depressed vitamin D levels in patients with DM2 are associated with a higher prevalence of microvascular complications particularly nephropathy, retinopathy, and neuropathy $[5,9,10]$. Food supplementation with vitamins $D, C$, and $E$ is recommended not only as prevention, but also for modulation of inflammatory and oxidative stress [8]. Correlation of vitamin D deficiency with risk of development of DR is not acknowledged by some authors. The same authors, however, agree with the importance of vitamin $D$ for the risk of insulin resistance via its effects on insulin receptors with subsequent induction of systemic inflammation and obesity [6]. Extremely low levels of vitamin $D$ were found in all tested patients; healthy population of the same age demonstrates a median level of $18 \mathrm{ng}$. Glucans have a solid history in reducing the diabetes and insulitis. In human studies, glucan in food reduced glycemic index in DM2, reduced postprandial blood glucose and insulin, and, when used as glucan-enriched bedtime snacks, it reduced nocturnal blood glucose levels in diabetic children
[37-39]. In addition, glucan improved wound healing in diabetic mice and prevented diabetes and insulitis in rats $[\mathbf{4 0 , 4 1 ]}$. Beta glucans were used inthe treatment of diabetes mellitus and in the prevention/reduction of cardiovascular diseaserisks [25]. The use of glucan resulted in significant improvement of skin conditions on lower extremities in five of seven patients with manifestations of polyneuropathy. Another study, using a cream with $3 \%$ glucan,reported significant acceleration of skin healing [42]. The role of glucan's effect on metabolism has been reported in an interesting review by Cloeten et al [43].

Functional food supplemented with glucan represents an important perspective not only for treatment, but also for prevention of diabetes mellitus and additional diseases, and possibly leading to reduce healthcare costs and disease prevalence $[11,12]$.

\section{Competing interests}

The authors declare that they have no competing interests.

\section{Authors' contributions}

\begin{tabular}{|l|c|c|c|c|c|c|c|c|}
\hline Authors' contributions & JR & MZ & VV & VK & IS & IL & JP & LRD \\
\hline Research concept and design & $\checkmark$ & $\checkmark$ & -- & $\checkmark$ & $\checkmark$ & $\checkmark$ & $\checkmark$ & -- \\
\hline Collection and/or assembly of data & $\checkmark$ & $\checkmark$ & -- & $\checkmark$ & $\checkmark$ & $\checkmark$ & $\checkmark$ & $\checkmark$ \\
\hline Data analysis and interpretation & $\checkmark$ & $\checkmark$ & $\checkmark$ & $\checkmark$ & $\checkmark$ & $\checkmark$ & $\checkmark$ & $\checkmark$ \\
\hline Writing the article & $\checkmark$ & $\checkmark$ & $\checkmark$ & -- & -- & -- & -- & -- \\
\hline Critical revision of the article & $\checkmark$ & $\checkmark$ & $\checkmark$ & -- & -- & -- & -- & -- \\
\hline Final approval of article & $\checkmark$ & $\checkmark$ & $\checkmark$ & $\checkmark$ & $\checkmark$ & $\checkmark$ & $\checkmark$ & $\checkmark$ \\
\hline Statistical analysis & $\checkmark$ & -- & -- & -- & -- & -- & -- & $\checkmark$ \\
\hline
\end{tabular}

Publication history

EIC: Anna Nasierowska-Guttmejer, Clinical Hospital of Ministry of Internal Affiars, Poland.

Received: 18-May-2018 Final Revised: 27-Jun-2018

Accepted: 03-Jul-2018 Published: 22-Jul-2018

\section{References}

1. Duh EJ, Sun JK and Stitt AW. Diabetic retinopathy: current understanding, mechanisms, and treatment strategies. JCI Insight. 2017; 2. | Article | PubMed Abstract | PubMed FullText

2. Solomon SD, Chew E, Duh EJ, Sobrin L, Sun JK, VanderBeek BL, Wykoff CC and Gardner TW. Diabetic Retinopathy: A Position Statement by the American Diabetes Association. Diabetes Care. 2017; 40:412-418. | Article | PubMed Abstract | PubMed FullText

3. Jenkins AJ, Joglekar MV, Hardikar AA, Keech AC, O'Neal DN and Januszewski AS. Biomarkers in Diabetic Retinopathy. Rev Diabet Stud. 2015; 12:159-95. | Article | PubMed Abstract | PubMed FullText

4. Nita M, Grzybowski A, Ascaso FJ and Huerva V. Age-related macular degeneration in the aspect of chronic low-grade inflammation (pathophysiological parainflammation). Mediators Inflamm. 2014; 2014:930671. | Article | PubMed Abstract | PubMed FullText

5. Bajaj S, Singh RP, Dwivedi NC, Singh K, Gupta A and Mathur M. Vitamin $\mathrm{D}$ levels and microvascular complications in type 2 diabetes. Indian J Endocrinol Metab. 2014; 18:537-41. | Article | PubMed Abstract | PubMed FullText

6. Bonakdaran $\mathrm{S}$ and Shoeibi N. Is there any correlation between vitamin D insufficiency and diabetic retinopathy? Int J Ophthalmol. 2015; 8:32631. | Article | PubMed Abstract | PubMed FullText

7. Ebbo M, Patient M, Grados A, Groh M, Desblaches J, Hachulla E, Saadoun D, Audia S, Rigolet A, Terrier B, Perlat A, Guillaud C, Renou F, Bernit
E, Costedoat-Chalumeau N, Harle JR and Schleinitz N. Ophthalmic manifestations in IgG4-related disease: Clinical presentation and response to treatment in a French case-series. Medicine (Baltimore). 2017; 96:e6205. | Article | PubMed Abstract | PubMed FullText

8. Garcia-Bailo B, El-Sohemy A, Haddad PS, Arora P, Benzaied F, Karmali M and Badawi $A$. Vitamins $D, C$, and $E$ in the prevention of type 2 diabetes mellitus: modulation of inflammation and oxidative stress. Biologics. 2011; 5:7-19. | Article | PubMed Abstract | PubMed FullText

9. Long $M$, Wang $C$ and Liu D. Glycated hemoglobin A1C and vitamin D and their association with diabetic retinopathy severity. Nutr Diabetes. 2017; 7:e281. | Article | PubMed Abstract | PubMed FullText

10. Luo BA, Gao F and Qin LL. The Association between Vitamin D Deficiency and Diabetic Retinopathy in Type 2 Diabetes: A MetaAnalysis of Observational Studies. Nutrients. 2017; 9. | Article I PubMed Abstract | PubMed FullText

11. Tessari $P$ and Lante A. A Multifunctional Bread Rich in Beta Glucans and Low in Starch Improves Metabolic Control in Type 2 Diabetes: A Controlled Trial. Nutrients. 2017; 9. | Article | PubMed Abstract | PubMed FullText

12. Vetvicka V, Sima P and Vannucci L. Beta glucan as therapeutic food, In A. M. Holban and A. M. Grumezescu (eds), Handbook of Food Bioengineering. Therapeutic Foods. 2018; 239-256.

13. Pickup JC. Inflammation and activated innate immunity in the 
Richter et al., Pathology Discovery 2018,

pathogenesis of type 2 diabetes. Diabetes Care. 2004; 27:813-23. | Article I PubMed

14. Zavorkova M, Richter J, Vetvicka V and Liehnova I. Orbital IgG4associated diseases. Pathol Discov.2017, 5:4. | Article

15. Okazaki K and Umehara H. Are Classification Criteria for IgG4-RD Now Possible? The Concept of IgG4-Related Disease and Proposal of Comprehensive Diagnostic Criteria in Japan. Int J Rheumatol. 2012; 2012:357071 | Article | PubMed Abstract | PubMed FullText

16. Chan ASY, Mudhar H, Shen SY, Lang SS, Fernando M, Hilmy MH, Guppy NJ, Rennie I, Dunkley L and Al Jajeh I. Serum IgG2 and tissue IgG2 plasma cell elevation in orbital IgG4-related disease (IgG4-RD): Potential use in IgG4-RD assessment. Br J Ophthalmol. 2017; 101:1576-1582. | Article | PubMed

17. Ebbo M, Grados A, Bernit E, Vely F, Boucraut J, Harle JR, Daniel L and Schleinitz N. Pathologies Associated with Serum IgG4 Elevation. Int J Rheumatol. 2012; 2012:602809. | Article I PubMed Abstract | PubMed FullText

18. Hao M, Liu M, Fan G, Yang X and Li J. Diagnostic Value of Serum IgG4 for IgG4-Related Disease: A PRISMA-compliant Systematic Review and Meta-analysis. Medicine (Baltimore). 2016; 95:e3785. | Article | PubMed Abstract | PubMed FullText

19. Lang D, Zwerina J and Pieringer H. IgG4-related disease: current challenges and future prospects. Ther Clin Risk Manag. 2016; 12:189-99. | Article | PubMed Abstract | PubMed FullText

20. Li J, Ma JM and Ge X. Role of IgG4 serology in identifying common orbital lymphoproliferative disorders. Int J Ophthalmol. 2016; 9:275-7. | Article | PubMed Abstract | PubMed FullText

21. Mattoo H, Mahajan VS, Della-Torre E, Sekigami Y, Carruthers M, Wallace ZS, Deshpande V, Stone JH and Pillai S. De novo oligoclonal expansions of circulating plasmablasts in active and relapsing IgG4-related disease. J Allergy Clin Immunol. 2014; 134:679-87. | Article | PubMed Abstract | PubMed FullText

22. Xia CS, Fan CH and Liu YY. Diagnostic performances of serum IgG4 concentration and IgG4/IgG ratio in IgG4-related disease. Clin Rheumatol. 2017; 36:2769-2774. | Article | PubMed

23. McNab AA and McKelvie P. IgG4-Related Ophthalmic Disease. Part II: Clinical Aspects. Ophthalmic Plast Reconstr Surg. 2015; 31:167-78. | Article | PubMed

24. Andrew N, Kearney D and Selva D. IgG4-related orbital disease: a metaanalysis and review. Acta Ophthalmol. 2013; 91:694-700. | Article | PubMed

25. Chen J and Raymond K. Beta-glucans in the treatment of diabetes and associated cardiovascular risks. Vasc Health Risk Manag. 2008; 4:126572. | Article | PubMed Abstract | PubMed FullText

26. Muhammad IF, Borne $Y$, Hedblad B, Nilsson PM, Persson M and Engstrom G. Acute-phase proteins and incidence of diabetes: a population-based cohort study. Acta Diabetol. 2016; 53:981-989. | Article | PubMed Abstract | PubMed FullText

27. Luttrull JK and Dorin G. Subthreshold diode micropulse laser photocoagulation (SDM) as invisible retinal phototherapy for diabetic macular edema: a review. Curr Diabetes Rev. 2012; 8:274-84. | Article | PubMed Abstract | PubMed FullText

28. Zavorkova M and Prochazkova L. [Treating Diabetic Macular Edema by a Micropulse Laser - First Findings]. Cesk Slov Oftalmol. 2015; 71:223-8. | Article | PubMed

29. Rother KI. Diabetes treatment--bridging the divide. N Engl J Med. 2007; 356:1499-501. | Article

30. Oprita R, Oprita B, Berceanu D and Diaconescu IB. Overview of IgG4 - Related Disease. J Med Life. 2017; 10:203-207. | PubMed Abstract | PubMed FullText

31. Wolfson AR and Hamilos DL. Recent advances in understanding and managing IgG4-related disease. F1000Res. 2017; 6. | Article | PubMed Abstract | PubMed FullText

32. Gomez-Peralta F, Abreu C, Cruz-Bravo M, Alcarria E, Gutierrez-Buey G, Krakauer NY and Krakauer JC. Relationship between "a body shape index (ABSI)" and body composition in obese patients with type 2 diabetes.
Diabetol Metab Syndr. 2018; 10:21. | Article | PubMed Abstract | PubMed FullText

33. Yu KH, Chan TM, Tsai PH, Chen $\mathrm{CH}$ and Chang PY. Diagnostic Performance of Serum IgG4 Levels in Patients With IgG4-Related Disease. Medicine (Baltimore). 2015; 94:e1707. | Article | PubMed Abstract | PubMed FullText

34. Vidarsson G, Dekkers G and Rispens T. IgG subclasses and allotypes: from structure to effector functions. Front Immunol. 2014; 5:520. | Article | PubMed Abstract | PubMed FullText

35. Salah A, Yoshifuji H, Ito S, Kitagori K, Kiso K, Yamada N, Nakajima T, Haga H, Tsuruyama T and Miyagawa-Hayashino A. High Expression of Galectin-3 in Patients with IgG4-Related Disease: A Proteomic Approach. Patholog Res Int. 2017; 2017:9312142. | Article I PubMed Abstract | PubMed FullText

36. Fox RI and Fox CM. IgG4 levels and plasmablasts as a marker for IgG4related disease (IgG4-RD). Ann Rheum Dis. 2015; 74:1-3. | Article | PubMed

37. Braaten JT, Scott FW, Wood PJ, Riedel KD, Wolynetz MS, Brule D and Collins MW. High beta-glucan oat bran and oat gum reduce postprandial blood glucose and insulin in subjects with and without type 2 diabetes. Diabet Med. 1994; 11:312-8. | PubMed

38. Jenkins AL, Jenkins DJ, Zdravkovic U, Wursch P and Vuksan V. Depression of the glycemic index by high levels of beta-glucan fiber in two functional foods tested in type 2 diabetes. Eur J Clin Nutr. 2002; 56:6228. | Article | PubMed

39. Rami B, Zidek T and Schober E. Influence of a beta-glucan-enriched bedtime snack on nocturnal blood glucose levels in diabetic children. $J$ Pediatr Gastroenterol Nutr. 2001; 32:34-6. | Article | PubMed

40. Berdal M, Appelbom HI, Eikrem JH, Lund A, Zykova S, Busund LT, Seljelid $\mathrm{R}$ and Jenssen T. Aminated beta-1,3-D-glucan improves wound healing in diabetic db/db mice. Wound Repair Regen. 2007; 15:825-32. | Article I PubMed

41. Kida K, Inoue T, Kaino $Y$, Goto $Y$, Ikeuchi M, Ito T, Matsuda $\mathrm{H}$ and Elliott RB. An immunopotentiator of beta-1,6;1,3 D-glucan prevents diabetes and insulitis in BB rats. Diabetes Res Clin Pract. 1992; 17:75-9. | Article I PubMed

42. Majtan J and Jesenak M. beta-Glucans: Multi-Functional Modulator of Wound Healing. Molecules. 2018; 23. | Article I PubMed

43. Cloetens L, Ulmius M, Johansson-Persson A, Akesson B and Onning G. Role of dietary beta-glucans in the prevention of the metabolic syndrome. Nutr Rev. 2012; 70:444-58. | Article | PubMed

\section{Citation:}

Josef R, Martina Z, Vaclav V, Vlastimil K, Ivana S, Ivana L, Jitka P and Lucie RD. IgG4-Related orbital disease in patients with diabetic retinopathy: Effects of glucan and vitamin D supplementation. Pathol Discov. 2018; 6:1. http://dx.doi.org/10.7243/2052-7896-6-1 